\title{
Chapter 6 \\ Higher Education Practices for Social \\ Innovation and Sustainable Development
}

\author{
Laura Dryjanska, Jana Kostalova, and Davorka Vidović
}

\begin{abstract}
Social innovation and sustainable development should constitute learning objectives in higher education across disciplines, while encouraging collaboration among future professionals. The theoretical framework of the multidisciplinary theory of social representations applies the training model of scientist-practitioneradvocate to education aimed at social innovation. The contribution considers sustainable development in the light of the United Nations' Sustainable Development Goals (SDGs). This chapter discusses some higher education practices from two different countries and fields of study. In the Czech Republic, innovative ways of involving students in practical work experience consist of participation in existing community projects, creation of publicly presented content or involvement in reallife situations. These practices and examples of activities lead towards enhanced civic engagement and responsibility; and a sustainable approach of students. In Croatia, innovative interactive practices include rural pop-up hubs and action research projects. They have been applied in both public and private higher education institutions to boost students' engagement and critical thinking.
\end{abstract}

Keywords Scientist-practitioner-advocate $\cdot$ Social representations $\cdot$ Sustainable development goals $\cdot$ Multidisciplinary collaboration

\author{
L. Dryjanska $(\bowtie)$ \\ Biola University, Rosemead School of Psychology, La Mirada, CA, USA \\ e-mail: laura.dryjanska@biola.edu \\ J. Kostalova \\ University of Pardubice, Pardubice, Czech Republic \\ e-mail: Jana.Kostalova@upce.cz \\ D. Vidović \\ Faculty of Political Science University of Zagreb, Zagreb, Croatia \\ e-mail: davorka.vidovic@fpzg.hr \\ C. Păunescu et al. (eds.), Social Innovation in Higher Education, Innovation, \\ Technology, and Knowledge Management, \\ https://doi.org/10.1007/978-3-030-84044-0_6
}




\section{The Key Points of the Chapter Are the Following}

- To explore how social innovation and sustainable development act as learning objectives in higher education.

- To understand the relevance of a multidisciplinary mindset for social innovation.

- To describe the role of social representations in fostering social innovation.

- To clarify the relationship between social innovation and advocacy.

\section{Introduction}

This chapter discusses social innovation and sustainable development as learning objectives in higher education, related to the skillset and experiences of learning by doing (Aji \& Khan, 2019; Chang et al., 2014; Thompson, 2010). It is inspired by the most recent theoretical developments in order to propose a model of education that is replicable and based on best practices in different countries and from diverse disciplines. The most recent theoretical contributions recognize that sustainability is already dealt with on a theoretical and practical level and that the gradual incorporation of a responsible approach is occurring in many activities in society, including the delivery of education programs within universities (Rey-Garcia \& Mato-Santiso, 2020). This chapter stresses the importance of transferable skills (such as advocacy, communication, and problem-solving) acquired by students in different higher education settings, including private and public universities situated in the Czech Republic and Croatia. Examples of practices from these two countries serve as an illustration of the theoretical framework that builds on the current state of the art, adding the approach of a multidisciplinary mindset. In other words, the emphasis on multiple disciplines with their different (and sometimes conflicting) learning outcomes, enables students to see the global problems in society, such as racism or climate change, in a holistic way. For example, a paleontologist may want to stop a residential construction project due to a high probability of finding some fossils. Obviously, an architect will not be glad about a delay in the project delivery, which would have financial consequences for the construction company. A social worker may worry about the lack of housing for the people that were supposed to live at this location. If each professional considers the problem exclusively through the lenses of their discipline, conflict appears inevitable. What is needed in this situation is a critical mindset in order to foment social innovation informed by a multidisciplinary approach. This example points out the importance of a neo-endogenous approach, where local development is based on a consensus between top-down and bottom-up, whereby local communities determine the implementation of ventures that aim to increase the standard of life (Shucksmith, 2010). 


\section{State of the Art}

\subsection{Theoretical Approach}

Social Innovation in Relation to Sustainable Development Social innovation invites a positive way of thinking about problems that we encounter both in terms of nature and society. Social innovation recognizes the human capacity to ideate, plan and implement change meant to improve the wellbeing of the planet. It provides "new solutions to the needs of people, which have not been fulfilled by the existing market players or governmental bodies, which increase their life standards and welfare" (Paunescu, 2014, p. 106). Overall wellbeing improves as members of society work together towards specific goals, preferably driven by intrinsic motivation. The United Nations (2021) strive for sustainable development through the achievement of 17 distinct goals as outlined in the 2030 Agenda for Sustainable Development. This agenda provides a shared blueprint for people and the planet to flourish; social innovation can be seen as a pathway to reaching these goals. The linkages between the Sustainable Development Goals (SDGs) and the higher education landscape include an emphasis on quality education in the fourth goal, with specific targets to be reached by 2030 . Sterling (2016) notes that education can make a critically important contribution to progress towards the SDGs, but this is by no means inevitable. The United Nations' 17 SDGs have been used in research for the purpose of classifying the different social needs that require social innovation. For example, Eichler and Schwarz (2019) conclude that in the light of SDGs, social innovation can be seen as an event containing the following five aspects: social need, innovative element, implementation and execution, improvement, and relationships and collaborations. Furthermore, Millard (2018) notes that the UN acknowledges that social innovation approaches are needed as mainstream tools for delivering sustainable development, alongside large-scale public and private funding. In particular, bottom-up approaches towards social innovation play a crucial role in designing and delivering public goods and services in a gender sensitive manner to people from a lower socio-economic background, especially when based on local acceptance and advocacy campaigns. In other words, a neo-endogenous approach (Ray, 2006) appears as more appropriate for delivering sustainable results by promoting initiatives that are locally rooted, but oriented towards the wider environment.

Scientist-Practitioner-Advocate as a Social Innovator In the world of higher education, various models have been used to develop students' ability to solve complex problems by applying acquired knowledge. Prominent examples include: contextual learning (Suryawati \& Osman, 2017), game-based learning (Setyaningrum et al., 2018) and flipped classroom (Lin, 2019). The scientistpractitioner-advocate training model urges students to expand their roles as scientists and practitioners to incorporate social justice advocacy as part of a basic commitment to multicultural competence (Mallinckrodt et al., 2014). This tripartite model is based on interlocking strengths, in which rigorous research is a tool for advocacy, 
and professional practice involves advocating for clients, ultimately empowering them to advocate for themselves. Hunt et al. (2020, p. 2) define this approach as a "considerable shift in understanding the etiology of distress," recognizing how the scientist-practitioner-advocate model departs from a traditional psychological emphasis on an individual level and acknowledges the profound impact of sociopolitical factors. While originally developed in the field of psychology, the scientistpractitioner-advocate model lends itself well to a multidisciplinary application across different sectors that value evidence-based practice. (Turale \& Kunaviktikul, 2019). Prominent examples include: counselling (Goodman et al., 2018), education (Weber et al., 2019), and public service settings (Gray et al., 2020).

What is advocacy in the context of education and sustainable development as well as social innovation? Certainly, numerous definitions exist, yet the following one by Garrison et al. (2017), p. 738) seems particularly appropriate in the context of social innovation and higher education: "Advocacy is the effort to influence public policy through education and engagement of lawmakers, as well as other concerned stakeholders, with interests in certain policy outcomes." According to Shier and Handy (2015), social innovation in the light of advocacy refers to the adaptation or change as a result of emerging contextual factors within the external environment and internal demands. Social innovation has a broader sense and reach than advocacy; future graduates will need all their skills as scientists, practitioners, and advocates to promote it and engage in it. Yet it may be helpful to consider how specific knowledge and skills obtained during a specific academic program will interact with the key dimensions of social innovation, in order to provide efficient training for the contemporary workplace. Social innovation has been commonly defined as new solutions that meet a social need (de Wit et al., 2019), with the emphasis on the novelty of ideas and practices. As such, social innovation requires creativity, alongside critical thinking, problem-solving ability, and communication skills typically reinforced in advocacy training. This is in line with the expectation that higher education students would possess all these attributes on the successful completion of their studies.

During the Covid-19 pandemic, the adoption of a blended learning approach, a mixture of online and face-to-face learning, has become necessary in most higher education institutions. It has therefore become imperative to consider the scientistpractitioner-advocate model in the light of promoting social innovation through blended learning. Bowyer and Chambers (2017) noted that the improvement in course outcomes due to blended learning has been partially attributed to a more strategic use of classroom time and the focus on more engaging and meaningful activities. Another opportunity that online delivery offers is the fact that virtual learning environments can provide helpful data about student interaction with learning materials and offer metrics that can indicate student engagement (Homes, 2018). Blended learning is more suited to specific students, especially those who have a lot of commitments outside of their studies.

In research, social innovation among university undergraduate students has been operationalized as social innovation orientation, since students may not have yet 
engaged directly in social innovation, but they are open and willing to engage. However, before considering social innovation in the light of advocacy, it may be helpful to establish a common ground by considering the meaning of the term. The theory of social representations (Moscovici, 1963) stands out as a multidisciplinary framework that enables researchers to contextualize an abstract term.

Social Representations Theory Almost sixty years ago, Moscovici (1963) proposed a social psychological theory of how the meaning of the novel phenomenon was unpacked by different groups. The theory specifically discusses diffusion as more than "the process by which an innovation is communicated through certain channels over time among the members of a social system" (Valente \& Rogers, 1995 , p. 243). It acknowledges the process of transformation as ideas move in society. The higher education institution, as a specific institutionalized setting, seeks to promote a social innovation mindset. Moscovici has introduced the concept of social representation to emphasize the perception of an issue, which nevertheless includes its embodiment (O'Connor, 2017). The Dictionary of Psychology (APA, 2015) defines social representation as "a system, model, or code for unambiguously naming and organizing values, ideas, and conduct, which enables communication and social exchange among members of a particular group or community." According to Wagner (2017), social representations are overarching notions in two senses: as conceptually located across minds instead of within minds, and, as they unite, mental processes as well as behaviours and the social objects emerging thereof. It has been applied to the study of therapeutic relationship (Gelo et al., 2016), concentrating on its content and structure while using the central nucleus approach. This specific approach to the theory of social representations, also known as structural or central core, has been proposed by Abric (1993). According to Pareles Quenza (2005), most of the assumptions of this approach are grounded in traditional conceptions of social cognition and mental representations, and thus can be easily operationalized when attempting to reflect the sociocultural conditions of creation and transformation of thought. The central core theory posits that regardless of content, social representations are composed of different interrelated elements. These elements differ in terms of status and function. Certain ones form a central system, generating a sense of representation; stable and consensual (shared), their associative and symbolic properties appear as unnegotiable. Other elements form a peripheral system that consists of two levels. Flexible and scalable, the periphery allows adaptation to reality, differentiation of content and protection of the central system (Zouhri \& Rateau, 2015). The most instable part of a social representation, likely questioned and changing, is the contrast zone. When reflecting upon the structure of social representations, an interesting phenomenon is the mute zone, defined as a specific subset of cognitions available to a person, but not expressed in standard conditions due to social desirability, shame, stigma, or other factors. For example, when studying social representations of Gypsies in Europe, many participants were clearly aware of negative associations present in their culture but chose not to enlist them (Piermattéo et al., 2014). 
Since in social innovation people are facing potential changes, the theory of social representations may be useful in understanding the educational process that takes place when instructors attempt to achieve social innovation as a learning outcome. In particular, the central core theory explains how people in society process change by allowing the new knowledge, skills and competencies to enter their peripheral system. Students should be able to embrace change, seeing it as an opportunity and not as a threat. This, of course, will be related to their personalities and previous experiences in life. The more scenarios that an instructor can provide for the students to navigate change in a safe climate, the better equipped they should become to one day propose the change themselves and advocate for it. By experiencing these new scenarios, understanding the context, and adapting to changing circumstances, students engage in experiential learning that emphasizes social innovation in a "boundary-less classroom" (Kickul et al., 2010).

Why do social representations matter for understanding social innovation in higher education? First, social representations focus on the dynamic perception of abstract concepts such as learning. In order to be active proponents of change, both students and educators need to view it as beneficial. A study of students' perception about their active and cooperative learning showed that they valued it and felt more engaged (Cavanagh, 2011). Social representations theory is also helpful in assisting students in how their understanding of the world impacts the writing process, a necessary step in academic pursuits. Social innovation tasks should include wellwritten assignments that consider purpose, audience, and genre, thereby helping students to accomplish learning outcomes more effectively (Bean, 2011). When considering social representations in higher education, one should reflect upon what teaching means to educators. They may be hesitant to implement social innovation due to the fundamental paradox in research and teaching in higher education-for the most part, throughout the history, teaching-learning arrangements have been taken for granted by majority of academics and students (Bonwell \& Eison, 1991).

\subsection{Sustainable Development Goals and Social Innovation}

The main theoretical contribution of this chapter lies in applying the theory of social representations to higher education for social change and sustainability, in line with the scientist-practitioner-advocate model of education. It stems from the Sustainable Development Goals (SDGs) and the implementation of transformations needed to achieve them (Sachs et al., 2019). In particular, higher education can be crucial in encouraging individuals to change norms and behaviours through social activism.

In 2015, the United Nations proposed 17 SDGs included in the 2030 Agenda for Sustainable Development. These goals contain 169 targets and 232 indicators, such as the reduction of poverty, gender equality, decent work within sustainable economic growth, and climate action (Lambert et al., 2020). Quality education (SDG3) is a goal, but also a precursor to and an outcome of the other goals. Higher education, depending on the discipline, can be related to all SDGs, engaging students in course 
work that promotes projects in line with the goal descriptors. For example, a graduate student in a marine biology program works towards preserving, protecting, and sustainably using aquatic and marine ecosystems by ideating and implementing a project to restore a particular ecosystem during boat-based fieldwork. On the other hand, an undergraduate student who majors in law, may choose to write a literature review paper on the implementation of the international sea law, inspired by the same SDG, namely Life Below Water.

What is the relationship between the SDGs and social innovation, in the light of higher education? According to Ravazzoli and Valero (2020, p. 3), social innovation "can contribute significantly to making cities and communities more sustainable, inclusive, resilient and safer and plays a strategic role in achieving the SDGs." Social innovation initiatives enable citizens, including educators and students, to identify and challenge some current unsustainable models of living, while proposing new sustainable solutions in line with specific SDGs. The vision for a brighter future of people and the planet, laid out in the SDGs for 2030, considers social innovation as an essential component (Ravazzoli \& Valero, 2020), since sustainable development initiatives implement principles and practices of social innovations. Education is essential to achieve SDGs; in fact, higher education institutions across Europe have been making systemic changes to foster sustainability through a reorientation in education, research, operations, and community outreach activities (Aleixo et al., 2020). For example, the University of Bologna in Italy has adopted an approach consisting of a full and rooted embracement of the SDGs under a solid political will of the university governance (Paletta et al., 2020). Therefore, striving to achieve SDGs through social innovation in higher education is certainly in line with the Third Mission of universities - their role in knowledge society, including cooperation and social engagement projects, students and teachers on lifelong learning programs (SDG 4), spin off and start-ups born by academic entrepreneurship (SDG 8), and events with public engagement (SDG 11). The Third Mission of universities originated from the concept that all universities are a specific mix of these three functions: mass tertiary education, professional specialized higher education and research and academic training and research (Laredo, 2007).

The discourse on sustainable development and social innovation has largely inspired the discussion on the new education paradigm, that combine traditional knowledge and skills such as problem solving, critical thinking, collaboration, but also creativity, innovation, and ethics (Mota \& Oliveira, 2014). The move towards education for sustainable development sets several principles, such as: learning rather than teaching; lifelong and continuous rather than confined to a specified period, multi-sourced and accessed rather than top down, controlled, and orchestrated; empowering rather than socializing (indoctrinating); global and yet locale specific; capacity building to build abilities for critical thinking and problem solving; multi-disciplinary approach as opposed to a single new discipline; sensitive to gender and diversity; participatory and based on learning with peers (Gorana \& Kanaujia, 2016, pp. 26-27). 


\section{Practices for Social Innovation and Sustainable Development}

The following sections provide examples of educational practices promoting social innovation and sustainable development from two countries-the Czech Republic and Croatia. These best practice examples were collected at the beginning of 2021 . The methodological approach is inductive, exploratory, and descriptive and based on heuristics. In this sense, it is not based on a rigorous methodological framework, but uses inductive observation by which the authors identify existing practices in their professional environments. The purpose of such an approach is to illustrate theoretical assumptions with practical examples in different disciplines and in different types of higher education institutions (including both public and private) As it is based on convenience and a heuristic approach, it does not intend to draw generalized conclusions, therefore, the reader is being provided with indicative findings, but to point out the link between theory and practice and to open a discussion for future research based on more rigorous scientific methods.

\subsection{Examples of Best Practices in the Czech Republic}

The Higher Education Act in the Czech Republic defines a higher education institution as the highest rank in the educational system and attributes it a key role in scientific, cultural, social, technical, and economic development of society. The Act also includes the so-called "third role" of universities, which comprises the active role of universities in public discussion about social and ethical issues, while nurturing a culture of diversity and mutual understanding and while shaping civic society and preparation of young people for life in it. The Act presents universities as institutions which contribute with their research towards development on a national and regional level, and which collaborate with various levels of state administration, regional government, with the commercial and cultural scene and with other relevant partners (The Higher Education Act of the Czech Republic, 1998). This key role defined by law, then in practice, exhibits itself in many versions and forms of fulfilling it, also intertwining with the basic role of universities-education. The Ministry of Education, Youth and Sports of the Czech Republic presents universities in its long-term plan as an irreplaceable part of modern society, which provide a significant contribution towards cultural and economic growth and accept their share of responsibility for sustainable development (Ministry of Education, Youth and Sports of the Czech Republic, 2020). Universities therefore have a great affinity for pursuing a sustainable approach to the fulfilment of its role, both on a general level and in particular, within the framework of the educational process. ${ }^{1}$ Several

\footnotetext{
${ }^{1}$ This is ensured, among other things, via unconventional approaches to education (more actionoriented, emphasizing learning by doing education; education focuses less on teaching individuals
} 
universities in the Czech Republic are members of the Association of Social Responsibility or otherwise declare their attitude in the field of social responsibility.

Universities in the Czech Republic are active in the field of development, coming up with social innovations, as can be seen using examples from several universities in the Czech Republic as specified below.

Linking of Theoretical and Practical Education in a Creative Manner De Almeida et al. (2020) mentioned the importance of practical ways in higher education. It is possible to find many examples in practice, too. Tomas Bata University in Zlín links the subject of Project Management with practical experience in an original manner. Education of project management takes place in the form of a two-semester subject. Students are familiarised during education with the theory of project management in a block of lectures at the start of the semester. They subsequently apply the theoretical knowledge they have acquired in practice. Students become an actual project team, the aim of which is to ensure organization of an international conference focused on project management. This conference takes place on university premises every year. Students based on experiences with organization of the conference of students in higher years, prepare a project plan, and subsequently, over the course of two semesters, implement the necessary steps. At the end of the semester, they are responsible for the conference itself. Students rate this experience in a very positive light, highly praising the opportunity to verify their theoretical knowledge in practice and gain experience from the real environment of an actual project. This activity is also praised by experts and participants at the conference, who appreciate the opportunity to gain practical experience in project management while still studying at university, something which certainly increases the students' standing within the jobs market after the completion of their studies.

A similar approach allowing students to gain real practical experience is offered at Charles University. Other than theoretical preparation, journalism students get involved in preparation of output, which is published during their studies. Students prepare the bi-monthly newspaper "Fleš", where they take turns to try out the role of an editor, a proof-reader, and an author of various types of journalistic texts, thus gaining an accurate idea about the various work duties associated with the production of a newspaper or magazine. Similarly, during their studies students participate in the creation of a publicly available on-line news service called CAROLINA, where they work in the editorial office of an on-line news platform. Radio and video reports or the photographic works of students are also presented publicly. Involvement of students in the creation of newspaper "Fleš" and on-line news blog CAROLINA, presented publicly, increases their accountability for the quality of the output, with students not only completing course work, but also being able to

in a classroom setting and more on learning-by-doing activities in a group setting and a network context), but also in the other activities performed by universities in partnership with other entities specified in the Triple or Quadruple Helix Models) (Rasmussen \& Sørheim, 2006; Etzkowitz, 2001). 
compare their output with professional output created by journalists or editors. It gives them a greater insight into the actual world of work.

Another example of using this approach is provided by the University of Pardubice, which prepares a regular project day for students pursuing HR Management and as support for career consultancy. Within this framework, students try out participation in a selection procedure to fill a specific position at work using the Assessment Centre tool under the patronage of actual HR managers from the world of work. Partner enterprises prepare individual or team tasks to perform in the Assessment Centre, similar in nature to those used in real selection procedures. Under the supervision of HR managers, students perform the required tasks and gain feedback at the end of the process. This gives them an insight into the work of HR specialists, while also helping them on a personal career level, as the feedback relates to evaluation of their involvement during the project day from the point of view of HR specialists. Participating students have been asked about their evaluation of this activity. Students highly rate this opportunity to gain real contact with experts from the world of work and the possibility of trying out the role of a job applicant during a selection procedure. They recognize the greatest benefits as the provision of feedback, recommendations by HR specialists on how to behave in a similar situation, and the positive and negative impressions of the HR specialists regarding their involvement in the project. The HR specialists have been asked about the benefits from their point of view as well. HR specialists from the world of work also praise this activity. They gain an idea about the abilities of current students and in many cases, students leave the project day on the topic of the Assessment Centre with a real offer of work once they have completed their studies or even during their studies.

The linking of theoretical and practical education is influenced by the field of study, with certain fields more amenable than others. Nevertheless, an innovative approach allowing students a real insight into practical work based on this principle can be introduced into the curriculum regardless of the field of study. It also supports the fulfilment of SDGs. The ever-expanding partnerships between universities and the entities around them (enterprises, public institutions and the non-profit sector, etc.), according to the specialization of the universities and their faculties, could be of great benefit in this field. It is an expanding trend that is increasing in importance both globally and in the Czech Republic (Tetrevova \& Vlckova, 2018; Tetrevova \& Vlckova, 2020).

\section{Education Leading towards Civic Responsibility, Engagement, and a Sustainable Approach Weber et al. (2021) presented a complex system approach of the involvement of sustainability in education processes within higher education. The Czech University of Life Sciences in Prague includes in its strategy a responsible approach and attempts to apply this approach within the framework of education of students. Since 2018, the university has been organizing a competition for students for submission of project proposals, which contributes towards the improvement of the sustainability of the campus or responsible behaviour by the students and employees of the university. Students who author the best proposals}


receive financial support for implementation of their projects with long-term impact and help during their preparation and implementation. A condition for selection of a project is that it has a long-term impact on the operation of the university. One project that was successful in the competition and subsequently implemented was the introduction of reusable plastic cups for drinks on the university campus. Another supported project was the creation of a reuse centre called FREESHOP, whereby students could donate functional items or clothing to fellow students. Specific areas were planted on campus with edible fruits and berries for students to freely pick; a flower meadow was planted in another area, thereby increasing biodiversity. Organic waste composters were installed next to the halls of residence, where students could dispose of their biological waste they produced during preparing of their meals. Other supported projects were focused on installing solar benches and a solar shelter where students could charge their phones and notebooks, and replacing lighting on the university campus with lower energy types. Apart from the competition, the Czech University of Life Sciences in Prague holds an annual conference on the topic of Social Responsibility of Universities, to which students also have access, allowing them to gain up-to-date information from this field or draw inspiration for other proposals of new sustainable projects.

Within the framework of the subject of Management of Innovations and Investments for Sustainable Development, the University of Pardubice, Faculty of Chemical Technology introduced a new activity leading towards the strengthening of civic responsibility and engagement in the field of sustainable development. In the theoretical part of the subject, students become familiar with a sustainable approach while proposing innovations; implementation/delivery strategies, and financing in enterprises within the chemical industry sector. Their task is also to come up with and propose a way they could contribute towards sustainability on a personal level, under the understanding that their proposal will be a commitment that they should subscribe to and comply with. Student commitments are focused on the sorting of waste or limiting creation of waste, the use of more environmentally friendly products, items from reuse centers, the limitation of use of disposable items, the reduction in energy consumption by choosing to travel by bike, the limitation of use of cars for transport or use of appliances, and lighting with lower energy demands. Commitments also relate to environmental protection, such as cleaning litter from the area where students live. The commitments frequently include an effort to influence the students' families, people around them, and to convince them of the need to make similar changes in their lives. Students praise the possibility of participating specifically in a sustainable approach and to relate the subject they are studying to themselves in the scope in which they can commit and to be true to this commitment. They approach this activity with great initiative and come up with very creative proposals for commitments. 


\subsection{Examples of Best Practices in the Croatia}

The education system in Croatia is going through a process of transformation, but despite some attempts, it has not been fully reformed to align itself with the new education paradigm for social innovation and sustainable development. However, in terms of the development of interactive and practical learning, one may witness a slow but relevant change. This mainly relates to the introduction of service learning, a teaching methodology that enables students to apply academic knowledge through teamwork by developing a project that solves a specific social problem (Modić Stanke \& Putarek, 2016: 1106). Originating in the U.S.A. in 1970s, the servicelearning model is focused on learning through experience or engagement in local communities (Ćulum \& Ledić, 2010). Therefore, it is largely involved with the promotion of social justice and civic responsibility (Meyers, 2009, according to Modić Stanke \& Putarek, 2016: 1107). Since 2006/2007, the first experimental model of service learning was introduced in a graduate course offered by the Department of Information and Communication Sciences at the Faculty of Humanities and Social Sciences University of Zagreb. Even though the model of service learning is not formalized in the education system, the term itself became well rooted. During the last decade and a half, several university courses across different disciplines introduced service learning, mostly by transforming their courses. There is no official data, but according to existing sources, there were 13 service-learning courses across Croatian universities (except the University of Zagreb) in 2013/2014 (McIlrath et al., 2016) and 27 service-learning courses in 2018, when they became recipients of the European Social Fund grants program. ${ }^{2}$ Thus, the service-learning model is still in a nascent stage in Croatia.

In Croatia, specific academic courses that teach social innovation and sustainable development are not broadly developed. However, there are some examples, including courses in both public and private universities and colleges that have integrated various models of practical learning in these fields. The first case is related to the course "Social Entrepreneurship and Social Innovation" that is a part of a study program Entrepreneurship Economics at the Vern' University in Zagreb, a private business university. The second one is related to the course "Sustainable Development and Social Innovation" at the Faculty of Political Science University of Zagreb, a public university.

Established in 2012/2013, the course "Social Entrepreneurship and Social Innovation" at Vern' University has been recognized as the first course in these topics at a higher education institution in Croatia. From the beginning, the course was organized in a way that valued applied knowledge and the involvement of students in work based learning, entrepreneurial projects, and practical initiatives. The course has developed and used several innovative models and tools for active practical

\footnotetext{
${ }^{2}$ The Office for Cooperation with NGOs allocated around 3.2 mil. Euro within ESF grant programme "Support to development of partnership between NGOs and higher education institutions for implementation of service learning courses".
} 
learning. For example, it uses the method of the "Guest's Challenge", where an invited guest, as a part of his/her lecture, presents a real challenging case or problem he/she is facing; the students are then invited to address it. The other example is students" participation in the "Social Impact Award", a regular competition and incubation program for students as social innovators (Social Impact Award, 2021). These models are all interesting and useful, but the one presented in detail will illustrate the high potential of innovative practical learning.

Rural Pop-up Hubs This model of service learning was introduced in 2018 as part of a project called "Social innovative pop-up rural hubs". In its pilot form, the model included the collaborative work of students and local stakeholders within two rural communities-one community, Štrigova, in Međimurje County in the northern part of Croatia, and the other one on the island of Vis, in the Split-Dalmatia County. The aim of the project was to establish a pop-up collaboration (hub), thereby involving different stakeholders such as higher education institutions, civil society organizations, students, and local citizens in the process of creating a solution for a specific problem posed by local social enterprises. The model enables students to care for and learn about sustainable rural development.

In an interactive, inclusive, and participative way, students had a chance not only to apply theoretical knowledge to addressing an actual need/challenge, but also to collaborate with "real" actors coming from different sectors and backgrounds.

The intention of this model is to raise students' awareness of the importance of activating local resources in addressing local needs and finding solutions for socioeconomic development (Ćorić \& Ciglar, 2020, p. 6). The model of a hub was recognized as suitable for bringing together different local stakeholders, people and organizations with different backgrounds, values, and perspectives. Minority groups, such as the Roma people, people with disabilities, or sexual and ethnical minorities are often included. Pop-up means that these gatherings are temporary, ad-hoc, impermanent in terms of structure and duration, and with a purpose clearly defined and understood by all actors. The temporality makes them easy to organize and to adopt to specific local actors' needs. The project starts with selecting a local community based on students' suggestions and their origins. Then, students and lecturers / professors gather information about the community and identify key actors. Specifically, they identify local social enterprises or social innovators, who will then be chosen for case studies. By communicating about the project, students and lecturers/professors try to induce interest among community members. The actual pop-up hub is organized on the spot and lasts approximately two days, during which a series of workshops takes place. Those workshops gather all stakeholders with the purpose of finding or creating an innovative solution to improve the business of selected cases (social enterprises or social innovators) towards sustainable development goals.

The course "Sustainable Development and Social Innovation" was established in 2020/2021 at the Faculty of Political Science as an elective course for students of political science and journalism. The main purpose of the course was to teach students the principles of sustainable development in both a critical and pragmatic 
way and to encourage them to be actively engaged in addressing social and ecological problems. Aside from guest lecturers coming from social enterprises, civil society organizations or innovative hubs, interactive debates, world cafes, and teamwork projects, the method of action research provides an innovative approach to applying knowledge to real settings and needs.

Action Research the "Sustainable Development and Social Innovation" program has prioritized practical activities around the method of action research. This approach has been recognized as successful in fostering learning and change towards sustainable development (Cebrián et al., 2015: 708). The main feature of this approach is that it is highly participative, collaborative, and is oriented towards change. It is based on a presumption that the community itself "knows best" and researchers (only) facilitate the process of recognizing existing local resources and needs, as well as the creation of a solution (Škrabalo et al., 2006).

In the first step, by working in pairs or teams, students need to identify a social or ecological problem in their local environment. The problem should be related to one or more sustainable development goals. For example, it may be around housing, health, discrimination, waste, vulnerable social groups, water, food, energy, education, etc. In the next step, students need to identify and connect to local stakeholders, such as civil society organizations, social enterprises, cooperatives, informal citizens' groups, or other social actors. By applying procedures from the action research method, they need to identify the existing needs, identify how different stakeholders understand the problem, what existing local resources exist, and the potential advantages or obstacles of possible models and solutions. According to the findings of initial research, students then facilitate the co-creation of sustainable solution (social innovation) together with other local stakeholders. In the final step, students need to reflect on how change was accepted and can be embedded in the social tissue of the local community, as well as to reflect on the entire process as a learning experience.

In its nature, the action research approach is highly participative and inclusive; students do not deal with an imagined problem to create a top-down solution for, but the opposite - they participate in gaining information and data from the field and co-creating solutions from the bottom-up with other stakeholders. The change created in this process is not only happening in local communities, but also within the students themselves. Thus, they do not only learn about the process of sustainable development but become the agents of change themselves.

\section{Discussion and Conclusions}

Aforementioned examples of higher education practices for social innovation and sustainable development show how education leading towards civic engagement, responsibility, and pointing towards a sustainable approach can be incorporated in fields of study regardless of their specialization. In most fields of study, the issue of 
sustainability is already dealt with on a theoretical and practical level. The gradual incorporation of sustainable processes and patterns is occurring in the majority of societal activities and subsequently has become embedded within the curricula and research priorities within universities (Rey-Garcia \& Mato-Santiso, 2020).

Innovative education practices for social innovations and sustainable development presented in this paper are closely related to the general policy framework given in UN's Sustainable development goals (SDGs). Except for the goal 17, which is more related to global partnership at the state level, most of SDGs have been addressed through these practices. All education practices are directly linked to the SDG4, focused on the quality and inclusiveness of education. Some models of education practices, such as pop-up hubs and action research may correspond to all SDGs from 1 to 16 , depending on the field of activities/industry of social enterprises they work with, or depending which field of social and ecological problems/needs they identify for action. Furthermore, in action research model, students are encouraged to choose any of SDGs as a framework for their action. The Table 6.1 presents the overview of the SDGs addressed by each innovative education practice.

An important trend and effort of higher education institutions to integrate civic engagement, responsibility, pointing towards a sustainable approach in their education policy, cooperating with other similar universities, and being a member of platforms focused on such activities is expanding. For example, abovementioned Czech universities have been ranked in UI Green Metric World Universities as universities aimed towards green policies and sustainability (Czech Universities, 2020).

Presented examples of higher education practices fit to a new education paradigm (Mota \& Oliveira, 2014; Gorana \& Kanaujia, 2016). There are several principles that given practices incorporate, thus providing valid illustrations of education for social innovation and sustainable development, particularly in: participative approach; learning rather than teaching, inclusivity and sensitivity towards gender diversity and other diversities, multi-sourced and accessed orientation to problem solving, creativity that combines theory with practical experience, collaboration, partnership, and learning with peers, neo-endogenous approaches, local-specific, but addressing global issues, multi-disciplinary, critical thinking, ethical, and empowering.

Based on such principles, it is possible to modify education in any study programs or subjects to fit the new education paradigm. Education leading towards civic engagement, responsibility, and pointing towards a sustainable approach could use the mentioned principles to bring social innovation, creativity, and accessibility in any type of specialization.

Multidisciplinary perspectives on education for social innovation and sustainable development represent distinct social contexts and approaches to education, including diverse models and curricula. However, while acknowledging the differences, it is noteworthy to observe some common elements of educational experiences proposed in the Czech Republic and Croatia. The case studies include: linking the theoretical and practical in a creative manner, civic responsibility, engagement, a sustainable approach, rural pop-ups, and action research. Engagement in advocacy, 
Table 6.1 Innovative education practices and SDGs

\begin{tabular}{|c|c|}
\hline Innovative education practices & SDGs \\
\hline $\begin{array}{l}\text { Linking of theoretical and practical education in a creative } \\
\text { manner }\end{array}$ & $\begin{array}{l}\text { Quality Education (SDG4) } \\
\text { Decent Work and Economic } \\
\text { Growth (SDG8) } \\
\text { Industry, Innovation and Infra } \\
\text { structure (SDG9) }\end{array}$ \\
\hline $\begin{array}{l}\text { Education leading towards civic responsibility, engage- } \\
\text { ment, and a sustainable approach. }\end{array}$ & $\begin{array}{l}\text { Quality Education (SDG4) } \\
\text { Affordable and Clean Energy } \\
\text { (SDG7) } \\
\text { Decent Work and Economic } \\
\text { Growth (SDG8) } \\
\text { Industry, Innovation and Infra } \\
\text { structure (SDG9) } \\
\text { Sustainable Cities and Communi } \\
\text { ties (SDG11) } \\
\text { Responsible Consumption and } \\
\text { Production (SDG12) }\end{array}$ \\
\hline Rural pop-up hubs & $\begin{array}{l}\text { No Poverty (SDG1) } \\
\text { Zero Hunger (SDG2) } \\
\text { Good Health and Well-being } \\
\text { (SDG3) } \\
\text { Quality Education (SDG4) } \\
\text { Gender Equality (SDG5) } \\
\text { Clean Water and Sanitation } \\
\text { (SDG6) } \\
\text { Affordable and Clean Energy } \\
\text { (SDG7) } \\
\text { Decent Work and Economic } \\
\text { Growth (SDG8) } \\
\text { Industry, Innovation and Infra } \\
\text { structure (SDG9) } \\
\text { Reduced Inequality (SDG10) } \\
\text { Sustainable Cities and Communi } \\
\text { ties (SDG11) } \\
\text { Responsible Consumption and } \\
\text { Production (SDG12) } \\
\text { Climate Action (SDG13) } \\
\text { Life Below Water (SDG14) } \\
\text { Life on Land (SDG15) } \\
\text { Peace and Justice Strong Institu } \\
\text { tions (SDG16) }\end{array}$ \\
\hline Action research & $\begin{array}{l}\text { No Poverty (SDG1) } \\
\text { Zero Hunger (SDG2) } \\
\text { Good Health and Well-being } \\
\text { (SDG3) } \\
\text { Quality Education (SDG4) } \\
\text { Gender Equality (SDG5) } \\
\text { Clean Water and Sanitation } \\
\text { (SDG6) } \\
\text { Affordable and Clean Energy } \\
\text { (SDG7) }\end{array}$ \\
\hline
\end{tabular}


Table 6.1 (continued)

\begin{tabular}{l|l}
\hline Innovative education practices & SDGs \\
\hline & Decent Work and Economic \\
Growth (SDG8) \\
Industry, Innovation and Infra \\
structure (SDG9) \\
Reduced Inequality (SDG10) \\
Sustainable Cities and Communi \\
ties (SDG1) \\
Responsible Consumption and \\
Production (SDG12) \\
Climate Action (SDG13) \\
Life Below Water (SDG14) \\
Life on Land (SDG15) \\
Peace and Justice Strong Institu \\
tions (SDG16)
\end{tabular}

Source: Authors

learning by doing, problem solving, critical thinking, and the neo-endogenous approach (Ray, 2006) constitute a common denominator of the proposed vision of higher education aimed at social innovation. On a theoretical level, the construct of social representations informs the emphasis on the context and community, inspiring students to understand the way of thinking that characterizes all actors involved and not only the key stakeholders. In particular, a reflection on social representations of active learning and teaching sheds light on the paradox of change in higher education, a potential barrier to implementing social innovation. The theory of social representations (Moscovici, 1963) integrated with the scientist-practitioner-advocate training model (Mallinckrodt et al., 2014) may be a helpful tool to consider when emphasizing social innovation in higher education. This theory offers an understanding of the structure of how individuals organize knowledge (Abric, 1993), including the central system and a peripheral system. The latter allows for adaptation of an innovative idea to reality, while differentiating the content and protecting the central system (Zouhri \& Rateau, 2015). Scientists-practitioners-advocates trained according to the model featured in this chapter can implement positive, innovative changes by analyzing and understanding how people think. Higher education should be aimed at teaching the students to communicate in an effective way, respecting different patterns of thinking of stakeholders involved. Thus, advocacy should be informed by science and practice.

The reflections emanating from this chapter indicate the importance of the local embeddedness of education for sustainable development and social innovation; in all cases, various models of collaboration and partnership between higher education institutions and local civil society organizations, entrepreneurs, innovators, and other stakeholders were established as polygons for teaching/learning. Thus, one of the main roles of academia--to be socially engaged within (local) communities and civil sector--is becoming more meaningful. The higher education sector has embraced a wider service to the community globally. In 1999, when the World Science 
Conference adopted the Budapest Declaration, social innovation theory confronted the decreasing hegemonic idea of progress (Oki, 2019). While paying attention to local communities, the education model for social innovation and sustainable development also follows the global aspirations related to the SDGs.

The varieties of practical learning examples presented here may raise some new research interests, for example in what (sustainable) ways and with what (social) impact students apply gained knowledge and skill in their future work and life. Hopefully, that may stimulate a further research in these topics.

\section{References}

\section{Journal Articles}

Abric, J.-C. (1993). Central system, peripheral system: Their functions and roles in the dynamics of social representations. Papers on Social Representations, 2, 75-78.

Aji, C. A., \& Khan, M. J. (2019). The impact of active learning on students' academic performance. Open Journal of Social Sciences, 7, 204-211. https://doi.org/10.4236/jss.2019.73017

Aleixo, A. M., Azeiteiro, U. M., \& Leal, S. (2020). Are the sustainable development goals being implemented in the Portuguese higher education formative offer? International Journal of Sustainability in Higher Education, 21(2), 336-352. https://doi.org/10.1108/IJSHE-042019-0150

Bowyer, J., \& Chambers, L. (2017). Evaluating blended learning: Bringing the elements together. Research Matters: A Cambridge Assessment Publication, 23, 17-26.

Cavanagh, M. (2011). Students' experiences of active engagement through cooperative learning activities in lectures. Active Learning in Higher Education, 12(1), 23-33.

Chang, J., Benamraoui, A., \& Rieple, A. (2014). Learning-by-doing as an approach to teaching social entrepreneurship. Innovations in Education and Teaching International, 51(5), 459-471. https://doi.org/10.1080/14703297.2013.785251

Ćulum, B., \& Ledić, J. (2010). Učenje zalaganjem u zajednici-integracija visokoškolske nastave i zajednice u procesu obrazovanja društveno odgovornih i aktivnih građana. Revija za socijalnu politiku, 17(1), 71-88.

de Almeida, I. N. S., Sampaio, M. A. P., Rolim, C. L. A., Capuzzo, D. D., \& Cezari, E. J. (2020). Teaching training in higher education and its perspectives: A test of the theoretical and practical ways. Humanidades \& Inovacao, 7(6), 498-501.

de Wit, A., Mensink, W., Einarsson, T., \& Bekkers, R. (2019). Beyond service production: Volunteering for social innovation. Nonprofit and Voluntary Sector Quarterly, 48(2S), 52S$71 \mathrm{~S}$.

Eichler, G. M., \& Schwarz, E. J. (2019). What sustainable development goals do social innovations address? A systematic review and content analysis of social innovation literature. Sustainability, 11(2), 522 .

Etzkowitz, H. (2001). The second academic revolution and the rise of entrepreneurial science. IEEE Technology and Society Magazine, 20(2), 18-29.

Garrison, E. G., DeLeon, P. H., \& Smedley, B. D. (2017). Psychology, public policy, and advocacy: Past, present, and future. American Psychologist, 72(8), 737-752. https://doi.org/10.1037/ amp0000209 
Gelo, O. C. G., Ziglio, R., Armenio, S., Fattori, F., \& Pozzi, M. (2016). Social representation of therapeutic relationship among cognitive-behavioral psychotherapists. Journal of Counseling Psychology, 63(1), 42-56.

Goodman, L. A., Wilson, J. M., Helms, J. E., Greenstein, N., \& Medzhitova, J. (2018). Becoming an advocate: Processes and outcomes of a relationship-centered advocacy training model. The Counseling Psychologist, 46(2), 122-153.

Gray, J. S., Kaslow, N. J., \& Allbaugh, L. J. (2020). Introduction to the special issue: Advocacy in public service settings. Psychological Services, 17(S1), 1-4. https://doi.org/10.1037/ ser0000497

Homes, N. (2018). Engaging with assessment: Increasing student engagement through continuous assessment. Active Learning in Higher Education, 19(1), 23-34.

Hunt, M. G., Miller, R. A., Stacy, M. A., Lynam, S., \& Carr, E. R. (2020). Public servant, silent servant: A call to action for advocacy training in public service settings. Psychological Services, 17(S1), 37-43. https://doi.org/10.1037/ser0000387

Kickul, J., Griffiths, M., \& Bacq, S. (2010). The boundary-less classroom: Extending social innovation and impact learning to the field. Journal of Small Business and Enterprise Development, 17(4), 652-663. https://doi.org/10.1108/14626001011088787

Lambert, L., Warren, M., Brulé, G., O’Brien, C., Murray, S., Mulay-Shah, A., Passmore, H.-A., Zelenski, J. M., Asfour, M., \& Alsubaiei, S. (2020). Perspectives: Using positive psychology and the United Nations' sustainable development goals to build a better world. Middle East Journal of Positive Psychology, 6, 1-28.

Laredo, P. (2007). Revisiting the third mission of universities: Toward a renewed categorization of university activities? Higher Education Policy, 20(4), 441-456. https://doi.org/10.1057/ palgrave.hep.8300169

Lin, Y. T. (2019). Impacts of a flipped classroom with a smart learning diagnosis system on students' learning performance, perception, and problem solving ability in a software engineering course. Computers in Human Behavior, 95, 187-196. https://doi.org/10.1016/j.chb.2018.11. 036

Mallinckrodt, B., Miles, J. R., \& Levy, J. J. (2014). The scientist-practitioner-advocate model: Addressing contemporary training needs for social justice advocacy. Training and Education in Professional Psychology, 8(4), 303-311. https://doi.org/10.1037/tep0000045

Meyers, S. A. (2009). Service learning as an opportunity for personal and social transformation. International Journal of Teaching and Learning in Higher Education., 21(3), 373-381.

Millard, J. (2018). How social innovation underpins sustainable development. In J. Howaldt, C. Kaletka, A. Schröder, \& M. Zirngiebl (Eds.), Atlas of social innovation: New practices for a better future (pp. 41-43).

Modić Stanke, K., \& Putarek, V. (2016). Odrednice interesa studenata za društveno korisno učenje. In O. Mojca (Ed.), International Conference EDUvision "Modern Approaches to Teaching the Coming Generations" (pp. 1105-1117). Ljubljana.

Moscovici, S. (1963). Attitudes and opinions. Annual Review of Psychology, 14, 231-260.

Mota, R., \& Oliveira, J. F. G. (2014). Combining innovation and sustainability: An educational paradigm for human development on earth. Brazilian Journal of Science and Technology, 1(2), $1-12$.

O'Connor, C. (2017). Embodiment and the construction of social knowledge: Towards an integration of embodiment and social representations theory. Journal for the Theory of Social Behavior, 47(1), 2-24.

Pareles Quenza, C. J. (2005). On the structural approach to social representations. Theory \& Psychology, 15(1), 77-100.

Paunescu, C. (2014). Current trends in social innovation research: Social capital, corporate social responsibility, impact measurement. Management \& Marketing, 9(2), 105.

Piermattéo, A., Monaco, G. L., Moreau, L., Girandola, F., \& Tavani, J. L. (2014). Context variations and pluri-methodological issues concerning the expression of a social representation: 
The example of the Gypsy Community. The Spanish Journal of Psychology, 17. https://doi.org/ $10.1017 /$ sjp. 2014.84

Rasmussen, E. A., \& Sørheim, R. (2006). Action-based entrepreneurship education. Technovation, 26(2), 185-194.

Rey-Garcia, M., \& Mato-Santiso, V. (2020). Enhancing the effects of university education for sustainable development on social sustainability: The role of social capital and real-world learning. International Journal of Sustainability in Higher Education, 21(7), 1451-1476. https://doi.org/10.1108/IJSHE-02-2020-0063

Sachs, J. D., Schmidt-Traub, G., Mazzucato, M., Messner, D., Nakicenovic, N., \& Rockström, J. (2019). Six transformations to achieve the sustainable development goals. Nature Sustainability, 2(9), 805-814.

Shier, M. L., \& Handy, F. (2015). From advocacy to social innovation: A typology of social change efforts by nonprofits. Voluntas: International Journal of Voluntary and Nonprofit Organizations, 26(6), 2581-2603. https://doi.org/10.1007/s11266-014-9535-1

Shucksmith, M. (2010). Disintegrated rural development? Neo- endogenous rural development, planning and place-shaping in diffused power contexts. Sociologia Ruralis, 50(1), 1-14.

Setyaningrum, W., Pratama, L. D., \& Ali, M. B. (2018). Game-based learning in problem solving method: The effects on students' achievement. International Journal on Emerging Mathematics Education, 2(2), 157-164.

Sterling, S. (2016). A commentary on education and sustainable development goals. Journal of Education for Sustainable Development, 10(2), 208-213. https://doi.org/10.1177/ 0973408216661886

Suryawati, E., \& Osman, K. (2017). Contextual learning: Innovative approach towards the development of students' scientific attitude and natural science performance. Eurasia Journal of mathematics, science and technology education, 14(1), 61-76. https://doi.org/10.12973/ejmste/ 79329

Tetrevova, L., \& Vlckova, V. (2020). Collaboration between higher education institutions operating in the Czech Republic and the non-academic sphere. European Education, 52(1), 68-79. https:// doi.org/10.1080/10564934.2019.1694846

Tetrevova, L., \& Vlckova, V. (2018). Benefits, limitations and measures concerning the development of cooperation between higher education institutions and external entities. Tertiary Education and Management, 24(4), 377-394.

Turale, S., \& Kunaviktikul, W. (2019). The contribution of nurses to health policy and advocacy requires leaders to provide training and mentorship. International Nursing Review, 66(3), 302-304.

Valente, T. W., \& Rogers, E. M. (1995). The origins and development of the diffusion of innovation paradigm as an example of scientific growth. Science Communication, 16(3), 242-273.

Wagner, W. (2017). Embodied social representation. Journal for the Theory of Social Behavior, 47 (1), 25-31.

Weber, S., Smith, J., Ayers, K., \& Gerhardt, J. (2019). Fostering disability advocates: A framework for training future leaders through interprofessional education. Psychological Services.

Weber, J. M., Lindenmever, C. P., Lio, P., \& Lapkin, A. A. (2021). Teaching sustainability as complex systems approach: A sustainable development goals workshop. International Journal of Sustainability in Higher Education, 22(8), 25-41. https://doi.org/10.1108/IJSHE-062020-0209

Zouhri, B., \& Rateau, P. (2015). Social representation and social identity in the black sheep effect. European Journal of Social Psychology, 45(6), 669-677. 


\section{Book and Book Chapters}

American Psychological Association. (2015). APA dictionary of psychology (2nd ed.). APA.

Bean, J. C. (2011). Engaging ideas: The Professor's guide to integrating writing, critical thinking and active learning in the classroom (2nd ed.). Jossey Baas.

Bonwell, C. C., \& Eison, J. A. (1991). Active learning: Creating excitement in the classroom. School of Education and Human Development, George Washington University.

Cebrián, G., Grace, M., \& Humphris, D. (2015). An action research project for embedding education for sustainable development in a university curriculum: Processes and prospects. In F. W. Leal, L. Brandli, O. Kuznetsova, \& A. Paço (Eds.), Integrative approaches to sustainable development at university level. World Sustainability Series. Springer.

Ćorić, G., \& Ciglar, D. (Eds.). (2020). Priručnik za ruralni razvoj pomoću mobilnih ruralnih hubova. LAG Međimuski doli i bregi.

Gorana, R. N., \& Kanaujia, P. R. (2016). A new paradigm of education towards sustainable development. In R. Gorana \& P. Kanaujia (Eds.), Reorienting educational efforts for sustainable development. Schooling for Sustainable Development. Springer.

Oki, S. (2019). Innovation' as an adaptation of 'Progress': Revisiting the epistemological and historical contexts of these terms. In Innovation beyond technology (pp. 47-62). Springer.

Paletta, A., Fochi, P., Toschi, T. G., \& Ubertini, F. (2020). Adoption of the SDGs as a reporting framework at the Alma mater Studiorum (University of Bologna) in Italy. In Sustainable development goals and institutions of higher education (pp. 185-197). Springer.

Ray, C. (2006). Neo-endogenous rural development in the EU. In P. J. Cloke, T. Marsden, \& P. Mooney (Eds.), Handbook of rural studies (pp. 278-291). Sage.

Ravazzoli, E., \& Valero, D. E. (2020). Social innovation: An instrument to achieve the sustainable development of communities. In W. Leal et al. (Eds.), Sustainable cities and communities, encyclopedia of the UN sustainable development goals. Springer Nature Switzerland. https:// doi.org/10.1007/978-3-319-71061-7_108-1

Škrabalo, M., Miošić-Lisjak, N., \& Papa, J. (2006). Mobilizacija i razvoj zajednica. Akcijsko istraživanje u Hrvatskoj. MAP savjetovanja.

Thompson, P. (2010). Learning by doing. Handbook of the Economics of Innovation, 1, 429-476.

\section{On-Line Documents}

Czech Universities (2020). CULS is the most sustainable Czech university. Accessed Jan 22, 2021, from https://www.czechuniversities.com/article/culs-is-the-most-sustainable-czech-univesity

McIlrath, L., Aramburuzabala, P., Opazo, H., Hopia, A., \& Grönlund, H. (2016). Europe Engage Survey of Civic Engagement \& Service-Learning Activities within the Partner Universities. Europe Engage Erasmus+project (European Union). Accessed Jan 15, 2021, from https:// researchportal.helsinki.fi/en/publications/europe-engage-survey-of-civic-engagement-amp-ser vice-learning-act

Ministry of Education Youth and Sport of the Czech Republic. (2020). Strategic plan of the Ministry for the field of higher education institutions for the period from 2021 June 2020. (in Czech). Accessed Jan 20, 2021, from https://www.msmt.cz/file/53277/

Social Impact Award (2021). Accessed Jan 22, 2021, from https://socialimpactaward.net/

The Higher Education Act of the Czech Republic. (1998). Act.No. 111/1998 Coll. On Higher Education Institutions and on Amendments and Supplements to Some Other Acts. Accessed Jan 19, 2021, from https://www.msmt.cz/areas-of-work/tertiary-education/the-higher-educationact?lang $=2$

United Nations (2021). The 17 Goals. Accessed May 3, 2021, from https://sdgs.un.org/goals 
Laura Dryjanska, $\mathrm{PhD}$ is Associate Professor at Rosemead School of Psychology of Biola University in Southern California and the Director of the Master's program in Positive Organizational Psychology. She obtained a PhD in social psychology (European PhD in Social Representations and Communication) in 2012 from the Sapienza University of Rome. Dr. Dryjanska maintains her ties with Italy as the research collaborator of the Eurispes Think Tank in Rome. Dr. Dryjanska's research interests focus on vulnerable populations and include migration, human trafficking, and intergenerational solidarity. Dr. Dryjanska endorses the vision of a citizen psychologist, well-rounded professional who applies the discipline to social issues, mindful of the public interests, diversity, and international perspectives. She is also a member of the Committee on Early Career Psychologists of the American Psychological Association (APA). Teaching in an APA-accredited doctoral program in clinical psychology, she promotes the scientist-practitioneradvocate training model.

Jana Kostalova, $\mathrm{PhD}$ is Assistant Professor at Faculty of Chemical Technology of University of Pardubice. She is a lecturer in the Bachelor's and Master's studying programs Economy and Management of Chemical Industry Enterprises. At this faculty, she obtained a Ph.D. in business economy and management in 2015. Dr. Kostalova's research interests focus on project management, project management maturity, sustainability generally and in project management, corporate social responsibility, and Industry 4.0 trends and its impact on society. She is author or co-author of more than 30 scientific papers, conference articles, and monographs. She is involved in international and national research projects. Dr Kostalova is certified project manager (IPMA certification, level C; PRINCE2 Foundation and PRINCE2 Practitioner). She is a member of project management association IPMA CZ.

Davorka Vidović, $\mathrm{PhD}$ is Assistant Professor at the Faculty of Political Science University of Zagreb, Croatia where she teaches courses Methods of Scientific Research, Sociology of Croatian Society, Sustainable Development and Social Innovation. She is a sociology scholar and holds a doctoral degree from the Faculty of Humanities and Social Sciences University of Zagreb. Her PhD thesis, focused on social entrepreneurship in Croatia, was a pioneering sociological study on this phenomenon in the country. For the last decade or more her research interests include various aspects of social enterprise, social entrepreneurship, cooperatives, social innovation, civil society, sustainable development. She regularly collaborates with international organizations and research networks on social economy and social enterprises such as CIRIEC, EURICSE, EMES. Also, she was engaged as an expert researcher for a several studies and reports lead by international organizations OECD, UNDP, World Bank etc. She is regularly involved in pro bono work in local community and social enterprises sector on consulting, evaluation of social entrepreneurship project, mentoring research studies and developing methodology for measuring social impact.

Open Access This chapter is licensed under the terms of the Creative Commons Attribution 4.0 International License (http://creativecommons.org/licenses/by/4.0/), which permits use, sharing, adaptation, distribution and reproduction in any medium or format, as long as you give appropriate credit to the original author(s) and the source, provide a link to the Creative Commons license and indicate if changes were made.

The images or other third party material in this chapter are included in the chapter's Creative Commons license, unless indicated otherwise in a credit line to the material. If material is not included in the chapter's Creative Commons license and your intended use is not permitted by statutory regulation or exceeds the permitted use, you will need to obtain permission directly from the copyright holder.

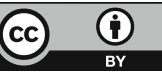

